Check for updates

Cite this: RSC Adv., 2021, 11, 16500

Received 27th January 2021

Accepted 23rd April 2021

DOI: $10.1039 / \mathrm{d} 1 \mathrm{ra00704a}$

rsc.li/rsc-advances

\section{The removal of 3-monochloropropane-1,2-diol ester and glycidyl ester from refined-bleached and deodorized palm oil using activated carbon}

\begin{abstract}
Elvi Restiawaty, (D) *abc Aulia Maulana, (D) ${ }^{\mathrm{C}}$ Neng Tresna Umi Culsum, ${ }^{\mathrm{C}}$ Christian Aslan, ${ }^{\mathrm{C}}$ Veinardi Suendo, ${ }^{d}$ Norikazu Nishiyama ${ }^{\mathrm{e}}$ and Yogi Wibisono Budhi ${ }^{\mathrm{ac}}$

Palm oil has fulfilled most of the oil needs in the food sector in the world. However, palm oil is indicated to contain small amounts of compounds that are harmful to humans, especially to infants. These toxic contaminants are 3-monochloropropanediol (3-MCPD) esters and glycidyl esters (GE), which are formed during the deodorization of palm oil at high temperatures. This study aims to reduce the 3-MCPD ester concentration in refined, bleached, and deodorized palm oil (RBDPO) through adsorption using activated carbon. The activated carbons were treated with heat and acid-washing using $\mathrm{HCl}$ at various concentrations and were characterized. The treatment altered the physicochemical characteristics of the activated carbon (surface area, pore volume, $\mathrm{pH}_{\mathrm{PZC}}$, and $\mathrm{CEC}$ ), resulting in the enhancement of its adsorption characteristics (adsorption capacity). The activated carbon treated with $2 \mathrm{~N} \mathrm{HCl}$ (AC $2 \mathrm{~N}$ ) was chosen as the proper adsorbent, due to better surface area, better pore volume, highest CEC value, and better positive charge in RBDPO. The 3-MCPD and GE adsorption capacity of AC $2 \mathrm{~N}$ was $1.48 \mathrm{mg} \mathrm{g}^{-1}$ and $29.68 \mathrm{mg} \mathrm{g}^{-1}$, respectively. The adsorption ability of pretreated activated carbon towards 3-MCPD esters was examined in a batch system at various adsorption temperatures. The 3-MCPD ester concentration in RBDPO was successfully reduced by up to $80 \%$ at $35{ }^{\circ} \mathrm{C}$ using the activated carbon treated with $2 \mathrm{~N} \mathrm{HCl}$ solution. On the other hand, the activated carbon was able to reduce the other contaminant of GE in RBDPO up to $97 \%$ from the initial concentration of GE.
\end{abstract}

\section{Introduction}

Among all countries worldwide, Indonesia is the highest producer and largest exporter of palm oil. It is estimated that Indonesian palm oil production will reach approximately 38.58 million metric tons in 2021, and it will increase in the coming years. It is also predicted that approximately 24.58 million metric tons of palm oil will be exported to other countries, while the rest (13.99 million metric tons) will be used for domestic consumption. ${ }^{1}$

Palm oil can be processed for production of its derivative products, such as cooking oil and margarine. The process consists of two main steps: extraction and refining. In the

${ }^{a}$ Research Group of Chemical Engineering Process Design and Development, Faculty of Industrial Technology, Institut Teknologi Bandung, Jalan Ganesha 10, Bandung 40132, Indonesia. E-mail: erestiawaty@che.itb.ac.id

${ }^{b}$ Department of Bioenergy Engineering and Chemurgy, Faculty of Industrial Technology, Institut Teknologi Bandung, Indonesia

${ }^{c}$ Department of Chemical Engineering, Faculty of Industrial Technology, Institut Teknologi Bandung, Bandung, Indonesia

${ }^{d}$ Division of Inorganic and Physical Chemistry, Faculty of Mathematics and Natural Sciences, Institut Teknologi Bandung, Indonesia

${ }^{e}$ Division of Chemical Engineering, Graduate School of Engineering Science, Osaka University, Japan extraction step, crude palm oil (CPO) is produced. Then, CPO undergoes the refining step, which consists of physical (steam) refining, degumming, bleaching, and deodorizing to produce refined, bleached, and deodorized palm oil (RBDPO). Next, RBDPO is fractionated to separate the olein and stearin. Finally, the stearin is packed as margarine products, while the olein is packed as cooking oil products. ${ }^{2}$

Every derivative product of palm oil contains 3monochloropropane-1,2-diol ester (3-MCPDE) and its related substance, glycidyl ester (GE). Both are formed by the deodorizing process at high temperature, which is approximately $200{ }^{\circ} \mathrm{C}^{3}$ Commonly, cooking oil produced from palm oil has the highest 3-MCPDE and GE concentrations at approximately 14 ppm. ${ }^{4}$

3-MCPDE and GE are considered to be harmful to human health because of their capability to induce tumors in rodents. 3-MCPDE is categorized as a nongenotoxic carcinogen, while GE is a genotoxic carcinogen. ${ }^{5}$ Because of this, these compounds must be permitted to enter the human body in the lowest amounts possible. The European Food Safety Authority stated that the maximum concentration of 3-MCPDE and GE that enters the body should be no more than $0.8 \mu \mathrm{g}$ per $\mathrm{kg}$ body weight per day. ${ }^{3}$ According to those recommendations, 
mitigation steps must be taken to remove those contaminants in palm oil.

There are some mitigation steps for reducing the amount of 3-MCPDE and GE in edible oils, namely, avoidance and minimization of precursors in the raw material, modification, extension of the refining process and removal of the esters after refining. ${ }^{4}$ In this research, removal of the esters after refining with an adsorption method was studied because it has a low cost and does not change the commercial process. The adsorption must be added between the deodorization and fractionation steps (because 3-MCPDE and GE are mostly formed during the deodorization step) ${ }^{3}$ and removed in both saturated and unsaturated fat products. Therefore, RBDPO which was produced after deodorization step and before fractionation step, ${ }^{2}$ was used in this research. Adsorption of 3MCPDE and GE had been studied by several researchers using many kinds of adsorbents such as zeolite, magnesium silicate, white clay, and activated carbon. ${ }^{6-8}$

Activated carbon is a low-cost adsorbent with excellent adsorption properties. It has been used for adsorption of various chemicals like heavy metal ions, ${ }^{9,10}$ dyes, ${ }^{11-13}$ and organic substances. ${ }^{14-16}$ In previous report, activated carbon has been applied to reduce the concentration of 3-MCPDE and GE. ${ }^{6,8}$ This research shows that activated carbon has a potential as a promising adsorbent for 3-MCPDE and GE removal. However, there is still lack information about the adsorption properties of the activated carbon in 3-MCPDE and GE removals from RBDPO. The adsorption properties studied in this paper include the surface area and pore volume of the adsorbent, the functional groups on the adsorbent surface, the inorganic elements on the adsorbent, $\mathrm{pH}$ of zero-point charge, cationexchange capacity (CEC), and isotherm model for the adsorption of 3-MCPD. Moreover, other research works used untreated palm oil or model solution such as hexadecane solution, ${ }^{6,7}$ while this research used RBDPO as raw material containing 3-MCPDE and GE. Therefore, activated carbon was studied intensively as the adsorbent to remove 3-MCPDE and GE in RBDPO.

\section{Material and methods}

\section{Materials}

RBDPO used in this research was from the palm oil industry in Lampung, Indonesia. Untreated activated carbon was bought from the local industry in Bandung, Indonesia. The 3monochloropropanediol-d5 (3-MCPD-d5) was used as an internal standard produced from Larodan, Sweden. The chemical reagents used in this experiment were analytical grade and included the following: acetone, ammonium sulfate, chloric acid, ethyl acetate, heptane, methyl tert-butyl ether, nitric acid, phenylboronic acid, potassium hydroxide, potassium nitrate, sodium hydroxide, sodium methoxide, and sulfuric acid.

\section{Adsorbent pretreatment}

Activated carbon was used in this research as an adsorbent, which was analyzed by CHN Analyzer (LECO CHN 628,
Netherlands), on Chemical Analysis Laboratory, Research Center for Chemistry-Indonesian Institute of Sciences, Serpong, Indonesia. The composition of activated carbon was $75.34 \pm$ $1.27 \%-w$ carbon, $2.70 \pm 0.12 \%-w$ hydrogen, $0.24 \pm 0.08 \%-w$ nitrogen, and $21.72 \pm 1.22 \%$-w oxygen on the dry and sulfur free basis. The activated carbon pretreatment method was heat and acid-wash pretreatment. The activated carbons were heated in an autoclave. The autoclave operating temperature, pressure, and time were $121{ }^{\circ} \mathrm{C}, 1 \mathrm{bar}$, and 60 minutes, respectively. The activated carbons were then acid-washed using $\mathrm{HCl}$. The concentration of $\mathrm{HCl}$ was varied for 1,2 , and $3 \mathrm{~N}$ with a ratio of $10 \mathrm{ml}$ of $\mathrm{HCl}$ solution per $1 \mathrm{~g}$ of activated carbon. Then, the activated carbon was agitated at room temperature for 24 hours. The activated carbons were then washed with demineralized water until the washing wastewater reached $\mathrm{pH}$ 5-7. Finally, the activated carbons were dried in the drying oven. The $\mathrm{HCl}$ treated activated carbon samples were then assigned as AC $1 \mathrm{~N}, \mathrm{AC} 2 \mathrm{~N}$, and $\mathrm{AC} 3 \mathrm{~N}$, respectively.

\section{Characterization of adsorbents}

BELSORP-Max (Microtrac BEL) was used to measure the nitrogen adsorption/desorption at $77 \mathrm{~K} .^{\mathbf{1 7}^{7}}$ The Brunauer, Emmet, and Teller (BET) method was used to determine the total surface area and the Barrett-Joyner-Halenda (BJH) method was used to determine the pore volume and pore size distribution. The functional groups formed on the surface of activated carbon were detected using Fourier Transform Infrared Spectroscopy (Prestige21, Shimadzu, Japan). The sample was preparation into pellet and analyzed in $2 \mathrm{~cm}^{-1}$ resolution between 4000 and $400 \mathrm{~cm}^{-1}$ in a spectral region. Characterization of inorganic elements on activated carbon was carried out using Orbis Micro X-ray fluorescence (XRF) analyzer operated at $40 \mathrm{kV}$.

\section{pH of zero-point charge ( $\left.\mathrm{pH}_{\mathrm{PZC}}\right)$ of the adsorbents}

The simplified potentiometric mass titration Method ${ }^{18}$ was used to determine $\mathrm{pH}_{\mathrm{PZC}}$. Blank solution was made by adding $9 \mathrm{ml}$ of $0.1 \mathrm{M} \mathrm{KNO}_{3}$ and $18 \mathrm{ml}$ of deionized water into a beaker glass. Then, $3 \mathrm{ml}$ of $0.01 \mathrm{M} \mathrm{KOH}$ was added into the solution. The solution was then titrated with $0.01 \mathrm{M} \mathrm{HNO}_{3}$ until constant $\mathrm{pH}$ was reached. For the sample, $150 \mathrm{mg}$ of adsorbent was added to into the blank solution. Then, $3 \mathrm{ml}$ of $0.01 \mathrm{M} \mathrm{KOH}$ was added and titrated with $0.01 \mathrm{HNO}_{3}$ until constant $\mathrm{pH}$ was reached. The value of $\mathrm{pH}_{\mathrm{PZC}}$ was determined from the intersection between the $\mathrm{pH}$ plots of the blank solution and the sample.

\section{Cation exchange capacity of the adsorbents}

Cation exchange capacity (CEC) was measured and calculated using a modified version of Boehm's technique..$^{\mathbf{1 9 2 0}}$ The treated activated carbon ( 0.1 gram) was placed into a vial bottle. Then, $20 \mathrm{ml}$ of $0.1 \mathrm{~N} \mathrm{NaOH}$ was added to the vial. The vial was shaken for 24 hours. After that, the solution in the vial was titrated using $0.1 \mathrm{~N} \mathrm{HCl}$. After the titration, the $\mathrm{NaOH}$ concentration after 24 hours was calculated. The CEC was calculated using eqn (1), ${ }^{19}$ 


$$
\mathrm{CEC}=\frac{\left(N_{1}-N_{2}\right)}{W} V
$$

where CEC = cation exchange capacity $\left(\mathrm{mmol} \mathrm{g}^{-1}\right), N_{1}=$ initial concentration of $\mathrm{NaOH}$ solution $(\mathrm{N}), N_{2}=$ concentration of $\mathrm{NaOH}$ solution after 24 hours shaken $(\mathrm{N}), V=$ initial volume of $\mathrm{NaOH}$ solution $(\mathrm{mL})$, and $W=$ weight of the activated carbon (g).

\section{Adsorption capacity of 3-MCPD}

Activated carbon that was used as the adsorbent was chosen based on its preferable characteristics observed in previous experiments. Laboratory scale adsorption was conducted within a round-bottom flask (see Fig. 1). The solutions of 3-MCPD in methanol were prepared with various concentrations of 5, 10, 15 and $40 \mathrm{ppm}$. The adsorption was done at $40{ }^{\circ} \mathrm{C}$ for two hours using $2 \%-w$ of the activated carbon. Finally, the mixture was centrifuged at $5000 \mathrm{rpm}$ and room temperature for 15 minutes. The solution was then prepared for GC-MS analysis.

\section{Adsorption of 3-MCPD from RBDPO}

RBDPO was poured into the round-bottom flask and then heated to a certain temperature. After that, the activated carbon was added at a ratio of $2 \% \mathrm{w} / \mathrm{w}$, and the adsorption was performed for 60 minutes. Finally, the RBDPO was separated with activated carbons by centrifugation ( $5000 \mathrm{rpm}$, room temperature, 15 minute). The adsorption of 3-MCPD from RBDPO was varied by the adsorption temperatures and the number of adsorption stages. The adsorption temperatures were varied from 35 up to $80{ }^{\circ} \mathrm{C}$. On the other variation, the adsorption was conducted in single stage and quadruple stages of batch processes at constant adsorption temperature. The adsorbent was always changed for every single stage.

The effect of adsorbent concentration on MCPD and GE removal from RBDPO

For this adsorption process, the concentration of activated carbon in RBDPO was varied by 1,2 , and $4 \%$. The adsorption

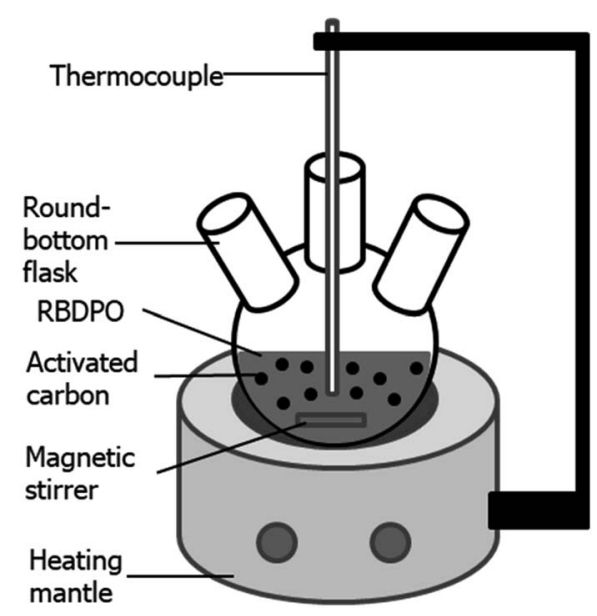

Fig. 1 The scheme of instrument for the laboratory scale adsorption. process was carried out with one-stage adsorption of batch process at temperature of $35^{\circ} \mathrm{C}$. After 2 hour adsorption, the sample was centrifuged at $5000 \mathrm{rpm}$ and room temperature for 15 minutes. The samples were then prepared for GC-MS analysis.

\section{Analysis of 3-MCPDE and GE}

The 3-MCPD in the RBDPO sample was analyzed by gas chromatography-mass spectrometry (GC-MS) with an indirect method. There were two assays in this analysis. The first assay was measurement of total 3-MCPD concentration in the sample. In this assay, the content of GE in RBDPO was converted into 3MCPD ester (3-MCPDE). The second assay was measurement of the 3-MCPD concentration. About $100 \mathrm{mg}$ sample was prepared in two vials which were labeled as Sample A and Sample B. Sample A was treated to convert GE into 3-MCPDE according to AOCS Cd 29a-13 with a little modification. ${ }^{21}$ Two milliliters of tetrahydrofuran and $30 \mu \mathrm{L}$ of acidified $\mathrm{NaCl}$ solution $\left(3 \mathrm{mg} \mathrm{ml}^{-1}\right.$ $\mathrm{NaCl}$ in $5 \% \mathrm{H}_{2} \mathrm{SO}_{4}$ solution) were added to vial A. The vial was then vortexed for 10 second and incubated at $50{ }^{\circ} \mathrm{C}$ for 15 minutes. After that, $3 \mathrm{ml}$ of $0.6 \% \mathrm{NaHCO}_{3}$ and $2 \mathrm{ml} n$-heptane were added to the vial A. The vial was then vortexed again for 10 seconds and the mixture was dried using $\mathrm{N}_{2}$ gas.

The dried contents gained in the vial $\mathrm{A}$ and the previous vial $\mathrm{B}$ were both treated according to a method developed by Federal Institute for Risk Assessment, ${ }^{22}$ i.e., method_82_FC-009-01 with a little modified. The sample then was then applied to GC-MS analysis. GC-MS analysis gave the total concentration of 3-MCPD from Assay A and the sole concentration of 3-MCPD from Assay B. Once the concentration values of Assay A and B gained, then the GE concentration can be calculated as written in eqn (2), ${ }^{6}$

$$
\text { GE concentration }(\mathrm{ppm})=(\text { Assay A }- \text { Assay } \mathrm{B}) \times \frac{M_{\mathrm{W} \text { glycidol }}}{M_{\mathrm{W} \text { mepd }}}
$$

where, Assay A = total concentration of 3-MCPD in the sample A, Assay B = concentration of $3-\mathrm{MCPD}$ in the sample $\mathrm{B}, M_{\mathrm{W}}$ glycidol $=$ molecular weight of glycidol $\left(74.08 \mathrm{~g} \mathrm{~mol}^{-1}\right), M_{\mathrm{W} \text { mcpd }}$ $=$ molecular weight of 3-monochoropropane-1,2-diol (110.54 g $\left.\mathrm{mol}^{-1}\right)$.

GC-MS analysis was done at Integrated Laboratory at Health Polytechnic of the Ministry of Health in Bandung, Indonesia. The GC-MS operating condition is shown at Table 1.

\section{Equilibrium isotherm study of adsorption}

The adsorption capacity of adsorbate at equilibrium condition could be calculated using eqn (3), ${ }^{13}$

$$
q_{\mathrm{e}}=\frac{\left(C_{\mathrm{i}}-C_{\mathrm{e}}\right)}{W} V
$$

where $q_{\mathrm{e}}=$ adsorption capacity of adsorbate $\left(\mathrm{mg} \mathrm{g}^{-1}\right), C_{\mathrm{i}}=$ initial concentration of adsorbate $\left(\mathrm{mg} \mathrm{L}^{-1}\right), C_{\mathrm{e}}=$ concentration of adsorbate at equilibrium $\left(\mathrm{mg} \mathrm{L}^{-1}\right), V=$ initial volume of adsorbate solution (L), $W=$ weight of the activated carbon $(\mathrm{g})$.

In this study, five adsorption isotherm models were fitted to the data. Those models were Langmuir, Freundlich, Dubinin- 
Table 1 GC-MS operating condition

\begin{tabular}{ll}
\hline Parameter & Condition \\
\hline Brand & Agilent technologies \\
Type & GC $7890 \mathrm{~A}-\mathrm{MS} 5975$ \\
Oven temperature & $60{ }^{\circ} \mathrm{C}$ for 1 minute \\
& $6{ }^{\circ} \mathrm{C} \min ^{-1}$ to $90{ }^{\circ} \mathrm{C}$ for 1 minute \\
& $20{ }^{\circ} \mathrm{C} \min ^{-1}$ to $280{ }^{\circ} \mathrm{C}$ for 5 minutes \\
Time & 21.5 minutes \\
Injector temperature & $175{ }^{\circ} \mathrm{C}$ \\
Injection method & Split less \\
Ionization mode & Electron impact \\
Carrier gas & Helium UHP \\
Gas flow & 1.2 ml min ${ }^{-1}$ \\
Injection volume & $1 \mu \mathrm{L}$ \\
SIM parameter & $3-\mathrm{MCPD}: 91,147,196$ \\
Column type & $3-\mathrm{MCPD}-\mathrm{d} 5: 93,150,201$ \\
& $\mathrm{HP}-5 \mathrm{MS} 5 \%$ phenyl methyl silox
\end{tabular}

Raduskevich, Temkin, and Flory-Huggins. The Langmuir isotherm model is written in eqn (4), ${ }^{23}$

$$
q_{\mathrm{e}}=\frac{Q_{\mathrm{m}} K_{\mathrm{L}} C_{\mathrm{e}}}{1+K_{\mathrm{L}} C_{\mathrm{e}}}
$$

where $K_{\mathrm{L}}=$ Langmuir constant related to energy of adsorption capacity $\left(\mathrm{L} \mathrm{mg}^{-1}\right)$ and $Q_{\mathrm{m}}=$ maximum adsorption capacity $(\mathrm{mg}$ $\mathrm{g}^{-1}$ ). The linear form of Freundlich isotherm model is written in eqn $(5),{ }^{23}$

$$
q_{\mathrm{e}}=K_{\mathrm{f}} C_{\mathrm{e}}^{1 / n}
$$

where $K_{\mathrm{f}}=$ adsorption capacity at unit concentration $\left(\mathrm{mg} \mathrm{L}^{-1}\right)$ and $1 / n=$ adsorption intensity. Dubinin-Raduskevich isotherm model is represented in eqn (6)-(8), ${ }^{23}$

$$
\begin{gathered}
q_{\mathrm{e}}=q_{\mathrm{m}} \exp \left(-K_{\mathrm{DR}} \varepsilon^{2}\right) \\
\varepsilon=R T \ln \left(1+\frac{1}{C_{\mathrm{e}}}\right) \\
E=\frac{1}{\sqrt{2 K_{\mathrm{DR}}}}
\end{gathered}
$$

where $K_{\mathrm{DR}}=$ a constant corelated with free energy of adsorption, $q_{\mathrm{m}}=$ adsorption saturation capacity. $\varepsilon=$ polanyi potential that calculated from eqn (7), $R=$ ideal gas constant $(8.314 \mathrm{~J}$ $\mathrm{mol}^{-1} \mathrm{~K}^{-1}$ ), and $T=$ temperature $(\mathrm{K})$. Free energy of adsorption can be calculated using eqn (8).

Temkin isotherm model is represented in eqn (9), ${ }^{23}$

$$
q_{\mathrm{e}}=\frac{R T}{b} \ln \left(A C_{\mathrm{e}}\right)
$$

where $b=$ the Temkin constant related to heat sorption ( $\mathrm{J}$ $\left.\mathrm{mg}^{-1}\right) . A$ is Temkin isotherm constant $\left(\mathrm{L} \mathrm{g}^{-1}\right)$. Flory-Huggins isotherm model is shown in eqn (10), ${ }^{23}$

$$
\begin{gathered}
\frac{\theta}{C_{\mathrm{i}}}=K_{\mathrm{FH}}(1-\theta)^{n_{\mathrm{FH}}} \\
\theta=\left(1-\frac{C_{\mathrm{e}}}{C_{\mathrm{i}}}\right)
\end{gathered}
$$

$$
K_{\mathrm{FH}}=\exp \left(\frac{-\Delta G^{\circ}}{R T}\right)
$$

where $K_{\mathrm{FH}}$ is equilibrium constant $\left(\mathrm{L} \mathrm{mol}^{-1}\right)$ and $n_{\mathrm{FH}}$ is number of adsorbates occupying the adsorption sites. The $\theta$ is defined in eqn (11). The value of $K_{\mathrm{FH}}$ is used to calculate $\Delta G^{\circ}$ of the adsorption using eqn (12). All those models were fitted to the data nonlinearly using curve fitting toolbox in MATLAB R2016a software. $^{24}$

\section{Results and discussion}

\section{Characterizations of activated carbon}

$\mathrm{N}_{2}$ physisorption analyser using the BET method was used to identify the adsorbent adsorption isotherm and measure the specific surface area and pores volume. The isotherm curve is shown in Fig. 2. Fig. 2 shows that all activated carbons before and after treatment were isotherm type I. Isotherm type I indicates that the adsorbent was typically microporous, with the exposed surface locating almost completely inside the micropores, which left little or no external surface for further adsorption once filled with adsorbate. ${ }^{25}$ The type I is concave to $P / P_{0}$ axis, and the amount adsorbed reaches a limiting value $(P /$ $\left.P_{0} \rightarrow 1\right) . P / P_{0}$ is the relative pressure, which is the ratio of the adsorbate gas equilibrium pressure to its saturated equilibrium vapor pressure. ${ }^{25}$ It is obviously depicted in Fig. 2 that acid treatment can increase the volume of $\mathrm{N}_{2}$ adsorbed which indicates an increased pore volume.

The surface area and pore distribution of activated carbon before and after treatment is shown on Table 2 . The surface area of activated carbon before the treatment was $404 \mathrm{~m}^{2} \mathrm{~g}^{-1}$, lower than the activated carbon after the treatment. The acid treatment on activated carbon resulted in the inorganic compound removal, ${ }^{26}$ so that the surface area and pore volume of the activated carbon treated with $\mathrm{HCl}$ were increased. The micropore and mesopore volumes of the pre-treated activated carbon were increased. It can be obviously seen that the acid treatment on activated carbon enhanced the micropore and mesopore distributions. The percentage of micropore (more than 50\%) in

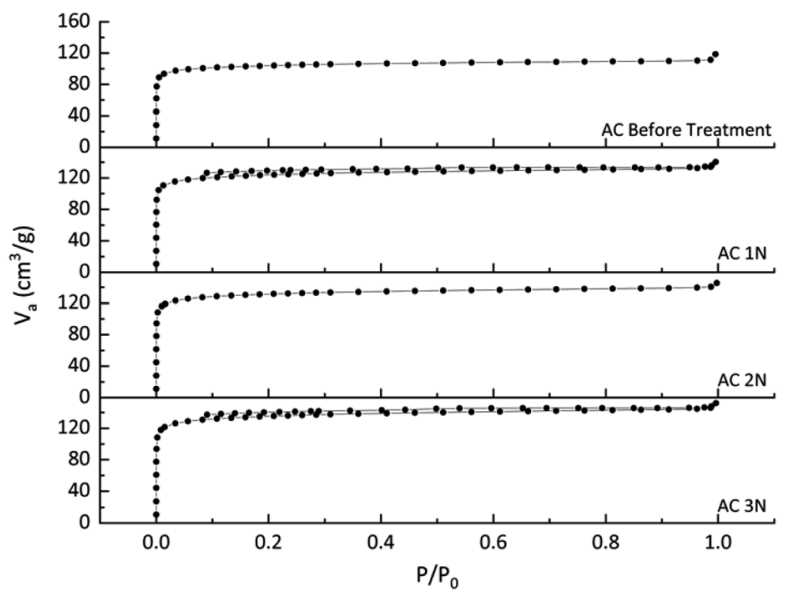

Fig. 2 Isotherm curve of activated carbons before and after treatment. 
Table 2 Specific surface area and pore volume of the activated carbons before and after treatment

\begin{tabular}{|c|c|c|c|c|c|}
\hline Adsorbents & $\begin{array}{l}S_{\mathrm{BET}} \\
{\left[\mathrm{m}^{2} \mathrm{~g}^{-1}\right]}\end{array}$ & $\begin{array}{l}V_{\text {micro }} \times 10^{3} \\
{\left[\mathrm{~cm}^{3} \mathrm{~g}^{-1}\right] \text { (fraction) }}\end{array}$ & $\begin{array}{l}V_{\text {meso }} \times 10^{3} \\
{\left[\mathrm{~cm}^{3} \mathrm{~g}^{-1}\right] \text { (fraction) }}\end{array}$ & $\begin{array}{l}V_{\text {macro }} \times 10^{3} \\
{\left[\mathrm{~cm}^{3} \mathrm{~g}^{-1}\right] \text { (fraction) }}\end{array}$ & $\begin{array}{l}V_{\text {total }} \times 10^{3} \\
{\left[\mathrm{~cm}^{3} \mathrm{~g}^{-1}\right]}\end{array}$ \\
\hline $\mathrm{AC}_{\text {Before treatment }}$ & 404 & $33.69(57 \%)$ & $16.85(28 \%)$ & $5.05(9 \%)$ & 59.34 \\
\hline $\mathrm{AC} 1 \mathrm{~N}$ & 486 & $40.72(56 \%)$ & $21.96(30 \%)$ & $5.41(7 \%)$ & 72.68 \\
\hline AC $2 \mathrm{~N}$ & 518 & $40.50(58 \%)$ & $21.16(30 \%)$ & $3.29(5 \%)$ & 69.46 \\
\hline $\mathrm{AC} 3 \mathrm{~N}$ & 532 & $43.70(57 \%)$ & $24.02(31 \%)$ & $4.65(6 \%)$ & 77.31 \\
\hline
\end{tabular}

Table 2 corresponds to Fig. 2 which showed the type I of isotherm model (typically microporous). The increasing surface area was influenced by the concentration of $\mathrm{HCl}$ used. The total pore volume of the pre-treated activated carbon was also influenced by the concentration of $\mathrm{HCl}$, but the total pore volume of AC $2 \mathrm{~N}$ was slightly lower than that of AC $1 \mathrm{~N}$. However, the concentration of $\mathrm{HCl}$ did not influence the ratio of activated carbon's pore size significantly.

The FTIR spectroscopy was used to identify the chemical groups on the activated carbon's surface before and after treatments. The results can be seen in Fig. 3. The functional group of activated carbon before treatment was slightly different with activated carbon after treatment. For untreated activated carbon, the peak appears at approximately $550 \mathrm{~cm}^{-1}$ resulting from $\mathrm{C}-\mathrm{C}$ stretching. Peaks at approximately $1258 \mathrm{~cm}^{-1}$ can be assigned to $\mathrm{C}-\mathrm{O}$ stretching from acids, esters, or ethers group. ${ }^{27}$ Other peaks appear at approximately $1517 \mathrm{~cm}^{-1}$ and $1799 \mathrm{~cm}^{-1}$ ascribed from $\mathrm{C}=\mathrm{O}$ stretching from carboxyl. ${ }^{28}$ For treated activated carbon, FTIR spectrum for every activated carbon after treatment did not show any significant difference. The broad peak of treated activated carbon at approximately $3421 \mathrm{~cm}^{-1}$ belongs to an $\mathrm{O}-\mathrm{H}$ bond, which indicates hydroxyl and carboxyl groups. ${ }^{29}$ Peak appearing at $1579 \mathrm{~cm}^{-1}$ is attributed to $\mathrm{C}=\mathrm{C}$ bond of aromatic ring. ${ }^{30}$ Another broad and strong peak at $1091 \mathrm{~cm}^{-1}$ belongs to $\mathrm{C}-\mathrm{O}$ bond, ${ }^{31,32}$ which is in lactone group. ${ }^{33}$

From the FTIR spectrum peaks, many oxygen-containing chemical groups appeared in the treated activated carbon.

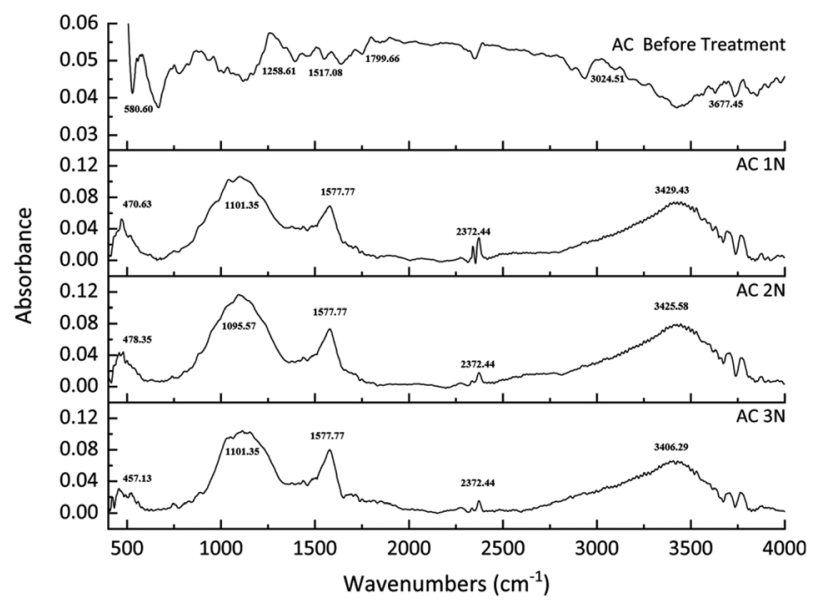

Fig. 3 FTIR results of the activated carbons before and after treatment.
Acid-washing the activated carbon can increase those chemical groups by oxidizing the surface of the activated carbon. ${ }^{29}$ Moreover, acid treatment could significantly increase the hydroxyl and carboxyl groups of the untreated activated carbon. $^{33}$

The concentration of lactone increased with the increase of acid concentration from $1 \mathrm{~N}$ to $2 \mathrm{~N}$, but it decreased at $3 \mathrm{~N}$. On the other hand, the concentration of carboxylic compound increased with the increase of the acid concentration. The modified activated carbon resulted in a change in acidity which is related to the amount and types of functional groups on the surface of the activated carbon. The decrease of $\mathrm{pH}_{\mathrm{PZC}}$ value and the total carbon acidity indicated a high concentration of acid sites. ${ }^{33}$

Adsorption process by using activated carbon involves interaction between adsorbate and carbon surface either through electrostatic or non-electrostatic including van der Waals forces, hydrogen bonding or hydrophobic interaction. ${ }^{34}$ $\mathrm{XRF}$ analysis was conducted on untreated and treated activated carbon (see Table 3), to determine the composition of inorganic elementals. According to XRF analysis carried out on untreated activated carbon, $K$ was the highest content, and was followed

Table 3 X-ray fluorescence (XRF) measurements of activated carbons before and after treatment

\begin{tabular}{lll}
\hline Element & $\mathrm{AC}_{\text {Before treatment }}(\%-\mathrm{w})$ & $\mathrm{AC} 2 \mathrm{~N}(\%-\mathrm{w})$ \\
\hline $\mathrm{Si}$ & 10.11 & 12.95 \\
$\mathrm{P}$ & 1.21 & $\mathrm{n} / \mathrm{a}$ \\
$\mathrm{S}$ & 2.75 & 6.58 \\
$\mathrm{~K}$ & 71.24 & 3.81 \\
$\mathrm{Ca}$ & 14.69 & 3.09 \\
$\mathrm{Fe}$ & $\mathrm{n} / \mathrm{a}$ & 0.67 \\
$\mathrm{Cl}$ & $\mathrm{n} / \mathrm{a}$ & 72.49
\end{tabular}

Table 4 Values of $\mathrm{pH}_{\mathrm{PZC}}$ and CEC of the activated carbons before and after treatment

\begin{tabular}{lll}
\hline & & \\
Adsorbents & $\mathrm{pH}_{\mathrm{PZC}}$ & $\begin{array}{l}\mathrm{CEC}(\mathrm{mmol} \\
\left.\mathrm{g}^{-1}\right)\end{array}$ \\
\hline $\mathrm{AC}_{\text {Before treatment }}$ & 7.65 & 1.0 \\
$\mathrm{AC}$ 1 N & 6.85 & 0.9 \\
$\mathrm{AC} 2 \mathrm{~N}$ & 7.3 & 1.8 \\
$\mathrm{AC} 3 \mathrm{~N}$ & 6.87 & 1.4
\end{tabular}


with $\mathrm{Ca}, \mathrm{Si}, \mathrm{S}$, and $\mathrm{P}$. Meanwhile, XRF analysis of activated carbon treated with $2 \mathrm{~N} \mathrm{HCl}$ showed that $\mathrm{Cl}$ was the highest content, which resulted from 24 hours acid-washed by $\mathrm{HCl}$ solution, and also hydrogen bonding between $\mathrm{Cl}^{-}$and the surface of activated carbon, although the bonding was poor. ${ }^{35-37}$ After $\mathrm{Cl}$ content, the chemical composition in the activated carbon followed with $\mathrm{Si}, \mathrm{S}, \mathrm{K}, \mathrm{Ca}$, and Fe. Based on the XRF analysis, heat treatment and acid wash could reduce ash content ( $\mathrm{Ca}, \mathrm{K}$, and $\mathrm{P}$ ) of activated carbon, which were impurities of the activated carbon. The Fe, S, and Si was slightly increased, possibly from impurities of acid solution and washing water of acid wash treatment, in the form of $\mathrm{Fe}^{2+}, \mathrm{Fe}^{3+}$, $\mathrm{SO}_{4}{ }^{2-}$, and $\mathrm{SiO}_{2} \cdot{ }^{38}$ In this analysis, carbon elemental was not detected before and after treatment using XRF analysis, because XRF analysis can only measure inorganic elements. However, the carbon organic was detected by CHN Analyzer as discussed

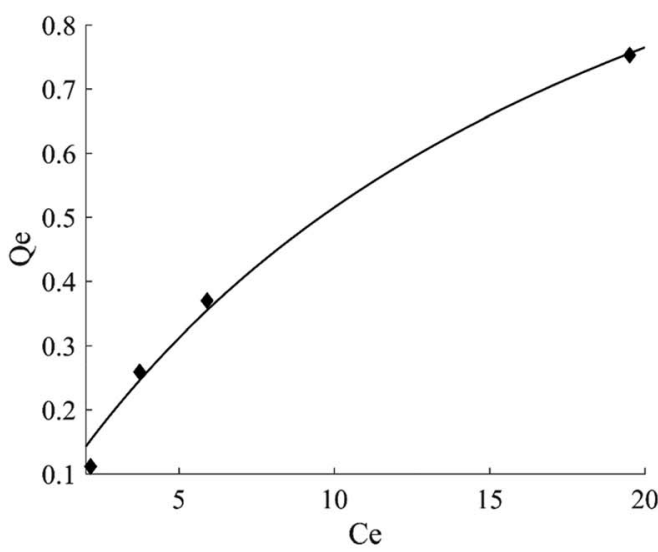

(a)

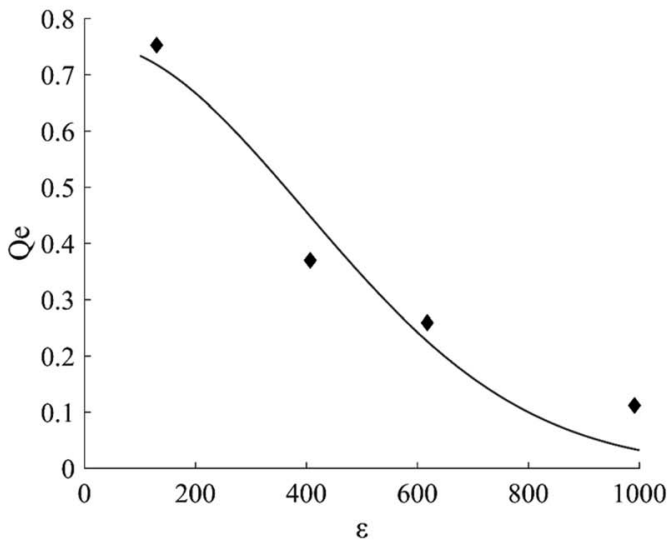

(c)

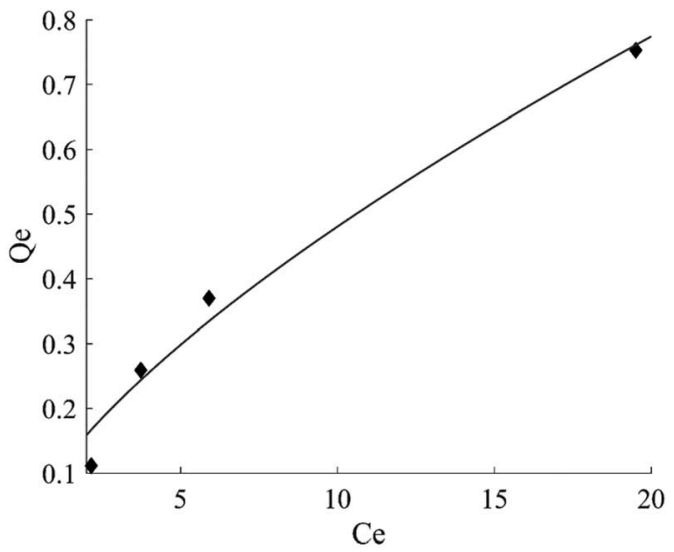

(b)

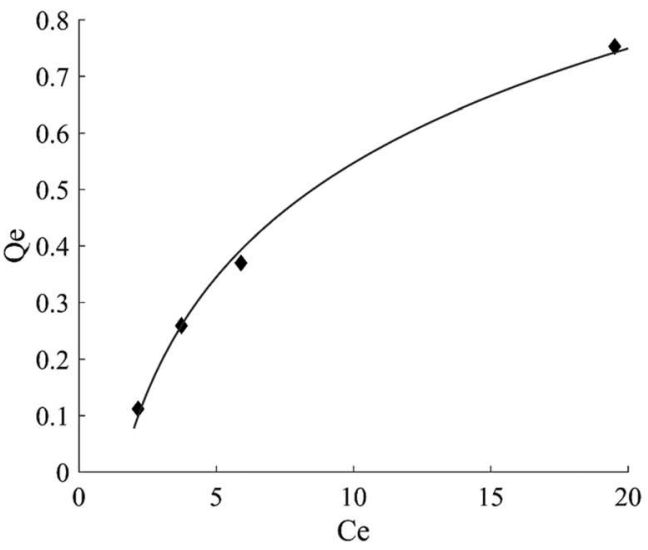

(d)

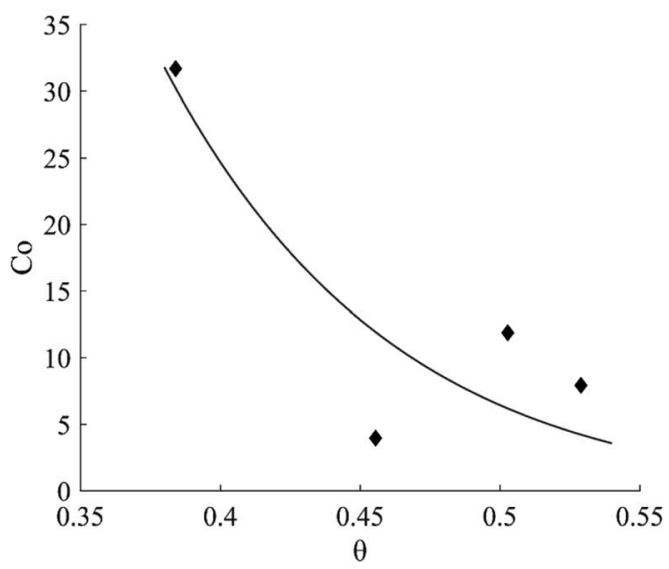

(e)

Fig. 4 Isotherm model plots of 3-MCPD adsorption, (a) Langmuir, (b) Freundlich, (c) Dubinin-Raduskevich, (d) Temkin, (e) Flory-Huggins. 
in Material and Methods section. The chemical composition detected on this activated carbon is slightly similar to the activated carbon used by Dittmann et al. (2020). ${ }^{39}$ The Si content in the activated carbon depends on the Si content in the original biomass of the activated carbon. ${ }^{40}$

\section{Activated carbon's $\mathbf{p H}_{\mathrm{PZC}}$ and CEC}

The $\mathrm{pH}_{\mathrm{PZC}}$ value represent the surface charge of carbon in solution and also exhibit the acidity/alkalinity of the adsorbent. The $\mathrm{pH}_{\mathrm{PZC}}$ and CEC value of the treated activated carbon are shown in Table 4. The value of $\mathrm{pH}_{\mathrm{PZC}}$ means that the activated carbon surface charge at that $\mathrm{pH}$ value is zero. In this research, the value of $\mathrm{pH}_{\mathrm{PZC}}$ of the treated activated carbon was slightly lower than the untreated activated carbon. This shows that the surface of activated carbon tends to basicity before treated using acid, while activate carbon is more neutral after treatment. This can be explained because the surface of the activated carbon contains many functional groups such as carboxylate and phenolic groups. ${ }^{41}$ This is in line with the results of research conducted by Beker et al. (2010), which states that the overall surface charge of activated carbon becomes positive at low $\mathrm{pH}$ conditions, whereas the overall surface charge of activated carbon becomes negative at high $\mathrm{pH}$ conditions. ${ }^{41}$ The value of $\mathrm{pH}_{\mathrm{PZC}}$ of the treated activated carbons did not differ significantly. The value range of $\mathrm{pH}_{\mathrm{PZC}}$ was from 6.85 to 7.33 which means that the surface charge of the activated carbon's surface is zero at those $\mathrm{pH}$ range. The values of $\mathrm{pH}_{\mathrm{PZC}}$ also indicate that the surface of the treated activated had balanced content between acidic groups and basic groups. ${ }^{\mathbf{6 , 4 2}}$

From the measurement of the CEC (Table 4), the acid wash treatment increased the CEC of activated carbon, except activated carbon treated with the $\mathrm{HCl} 1 \mathrm{~N}$, possibly because the acid concentration was low. Activated carbon treated with $\mathrm{HCl} 2 \mathrm{~N}$ had the highest value of CEC, which was $1.8 \mathrm{mmol} \mathrm{g}^{-1}$. The CEC of activated carbon is relatively low. ${ }^{43}$ However, that value was near the average of activated carbon CEC, which is $1.63 \mathrm{mmol}$ $\mathrm{g}^{-1} \cdot \cdot^{20,44-46}$

\section{Equilibrium studies of the 3-MCPD adsorption using treated activated carbon}

The adsorption of MCPD compounds was due to esterification of carboxyl groups on the activated carbon surface with the chloride site of $3-\mathrm{MCPD},{ }^{47}$ not the hydroxyl site or ester site.
Therefore, the isotherm model was measured with the adsorption of 3-MCPD solution as adsorbate solution.

The linear regression plot of every isotherm models can be seen at Fig. 4 and their parameter values are shown at Table 5. From the results, Langmuir, Freundlich, Dubinin-Raduskevich, and Temkin isotherm model had the high $R^{2}$ values and Temkin model was the highest, hence the most fit model for the adsorption of 3-MCPD. From Langmuir isotherm model, the maximum adsorption capacity was $1.48 \mathrm{mg} \mathrm{g}^{-1}$, different from the value from Dubinin-Raduskevich model which was $0.60 \mathrm{mg}$ $\mathrm{g}^{-1}$. The activation energy of 3-MCPD adsorption from the same model was $0.4 \mathrm{~kJ} \mathrm{~mol}^{-1}$. From Flory-Huggins isotherm model, the $\Delta G^{\circ}$ of the 3-MCPD adsorption was $-14.13 \mathrm{~kJ} \mathrm{~mol}^{-1}$, which means the adsorption process is spontaneous. Temkin isotherm model can be used to approximate the heat of 3-MCPD adsorption. ${ }^{23}$ From the results, the $K_{\mathrm{T}}$ and $b$ were $0.65 \mathrm{~L} \mathrm{~mol}^{-1}$ and $8914 \mathrm{~J} \mathrm{~mol}^{-1}$, respectively. Because the Temkin constant is related to heat of adsorption, it could be assumed that the heat of adsorption $(\Delta H)$ of 3 -MCPD was $-8914 \mathrm{~J} \mathrm{~mol}^{-1}$ (negative punctuation because the adsorption is exothermic). According to Desiraju and Steiner (1999), and Jeffrey and Saenger (1991), the bonding energy of adsorption in this research was weak hydrogen bond. ${ }^{36,37}$

\section{The effects of adsorption temperature and number of stages of adsorption on the 3-MCPDE removal}

In this investigation, the adsorbent used was activated carbon which had been treated with $2 \mathrm{~N} \mathrm{HCl}$ (AC $2 \mathrm{~N}$ ) because this adsorbent exhibited the highest $\mathrm{CEC}$ value. AC $2 \mathrm{~N}$ adsorbent exhibited slightly lower surface area and pore volume than AC $3 \mathrm{~N}$ adsorbent. However, AC $2 \mathrm{~N}$ adsorbent was better chosen as an adsorbent because its production process requires less $\mathrm{HCl}$ than the production process of AC $3 \mathrm{~N}$. This will have an impact on operating costs when the process is scaled up.

Concentration of 3-MCPDE in RBDPO was measured as total 3-monochloropropane-1,2-diol (3-MCPD) concentration in RBDPO. A measurement of 3-MCPDE cannot be taken directly with GC-MS; it needs to be in a non-esterified form to determine. Although 3-MCPD is also contained in RBDPO, its concentration is much lower than the concentration of 3MCPDE. ${ }^{48}$

GC-MS was used to analyze the sample before and after adsorption, and the results are shown in Fig. 5. The obtained

Table 5 Values of each parameter isotherm model for the adsorption of 3-MCPD

\begin{tabular}{|c|c|c|c|c|c|}
\hline Isotherm model & Parameters & & & & \\
\hline \multirow[t]{2}{*}{ Langmuir } & $Q_{\mathrm{m}}\left(\mathrm{mg} \mathrm{g}^{-1}\right)$ & $K_{\mathrm{L}}\left(\mathrm{L} \mathrm{mg}^{-1}\right)$ & & $R^{2}$ & RMSE \\
\hline & 1.48 & 0.05 & & 0.9860 & 0.0324 \\
\hline \multirow[t]{2}{*}{ Freundlich } & $n$ & $K_{\mathrm{f}}\left(\mathrm{mg} \mathrm{g}^{-1}\right)$ & & $R^{2}$ & RMSE \\
\hline & 1.45 & 0.10 & & 0.9692 & 0.0481 \\
\hline \multirow[t]{2}{*}{ Dubinin-Raduskevich } & $Q_{\mathrm{m}}\left(\mathrm{mg} \mathrm{g}^{-1}\right)$ & $K_{\mathrm{DR}}\left(\mathrm{mol}^{2} \mathrm{~J}^{-2}\right)$ & $E\left(\mathrm{~J} \mathrm{~mol}^{-1}\right)$ & $R^{2}$ & RMSE \\
\hline & 0.60 & $3.1710^{-6}$ & 397.339 & 0.9354 & 0.0854 \\
\hline \multirow[t]{2}{*}{ Temkin } & $\beta$ & $b\left(\mathrm{~J} \mathrm{~mol}^{-1}\right)$ & $A\left(\mathrm{~L} \mathrm{~mol}^{-1}\right)$ & $R^{2}$ & RMSE \\
\hline & 0.29 & 8914 & 0.651 & 0.9963 & 0.0204 \\
\hline \multirow[t]{2}{*}{ Flory-Huggins } & $n$ & $K_{\mathrm{FH}}\left(\mathrm{L} \mathrm{g}^{-1}\right)$ & $\Delta G^{\circ}\left(\mathrm{kJ} \mathrm{mol}^{-1}\right)$ & $R^{2}$ & RMSE \\
\hline & 6.15 & 228.5 & -14.134 & 0.6307 & 7.482 \\
\hline
\end{tabular}


RBDPO sample contained $19.67 \mathrm{ppm}$ of 3-MCPD. According to Figure 5, 3-MCPD concentration in RBDPO after the adsorption processes using the treated activated carbon was reduced, which showed that the pre-treated activated could remove the 3MCPDE in RBDPO.

The reductions of 3-MCPD concentrations were varied based on the process temperature and the stepwise stages of the process (see Fig. 5). At process temperature at a process temperature of $35{ }^{\circ} \mathrm{C}$ and four stages of the batch process, 3MCPDE removal was the highest at $80 \%$, which was better than the previous research showed. ${ }^{7}$ It indicates that lower temperature gives better reduction of 3-MCPDE concentration, and this corresponds to Cheng's research, ${ }^{6}$ which showed more efficient removal at the lower temperature. The batch stepwise process also seems to increase the removal efficiency of 3-MPCDE. However, at the temperature of $60{ }^{\circ} \mathrm{C}$, there only was a little change in the 3-MCPD concentration in RBDPO between 1- and 4-stages the adsorption process. The results indicated that the lower the temperature and the greater the number of batch adsorption stages resulted in higher 3-MCPD removal.

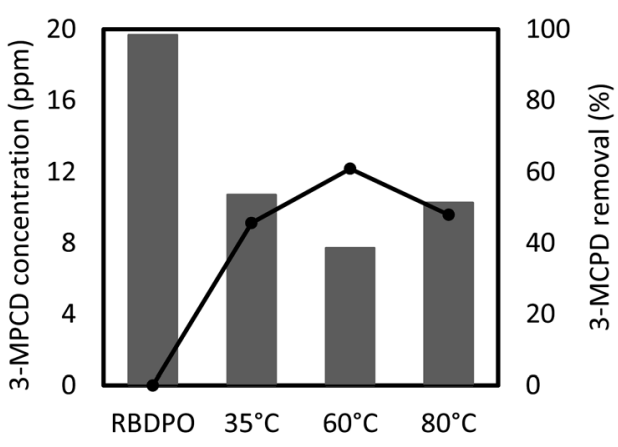

Adsorption temperature

(a)

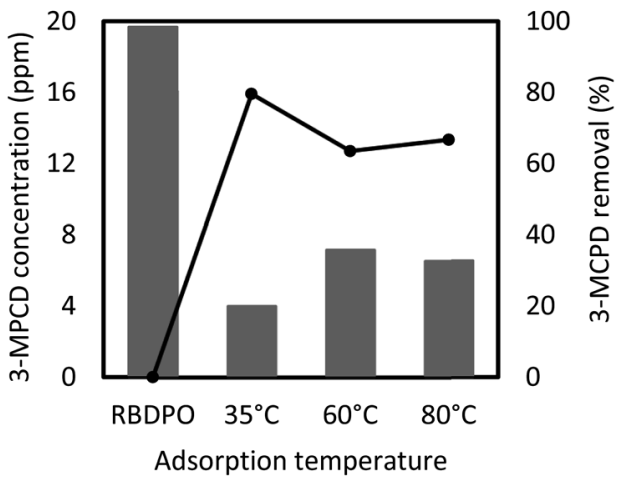

(b)

Fig. 5 Concentration of 3-MCPD (bar chart) and percent removal of 3-MCPD from RBDPO (circle with line) before and after adsorption at temperature of 80,60 , and $35^{\circ} \mathrm{C}$ in (a) single stage of batch process, and (b) quadruple stages of batch process.

\section{Effect of adsorbent concentration on 3-MCPD dan GE removal}

The effects of adsorbent concentration on 3-MCPD and GE removal were investigated, and the results are given in Fig. 6(a) and (b). The initial concentration of 3-MCPD and GE were $19.7 \mathrm{ppm}$ and $6.7 \mathrm{ppm}$, respectively. The concentration decreases and percentage of removal of 3-MCPD and GE from RBDPO before and after adsorption using various concentration of activated carbon are depicted in Fig. 6(a) and (b), respectively.

The initial GE concentration in RBDPO was 6.68 ppm and after the adsorption process using activated carbon, the final concentration could reach $0.2 \mathrm{ppm}$. The highest GE removal (97\%) was obtained when $2 \%-w$ activated carbon was applied as adsorbent. The adsorption capacity of GE by the activated carbon was detected at $29.68 \mathrm{mg} \mathrm{g}^{-1}$. Activated carbon generally has a hydrophobic surface so it is good for adsorbing non-polar molecules, such as GE. ${ }^{49}$ The similar result on GE removal was also obtained by Cheng et al. $(2017)^{6}$ that the adsorption GE from palm oil using acid-washed activated carbon could reach up to $95.5 \%$ at $T=35^{\circ} \mathrm{C}$. The results of GE removal in this study were slightly higher than those obtained by Cheng et al. (2017). The different can occur when the activated carbon pore structures, such as surface area and pore volumes, are different.

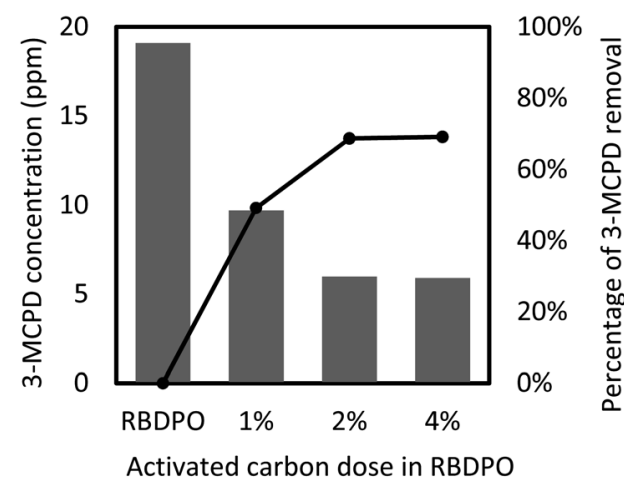

(a)

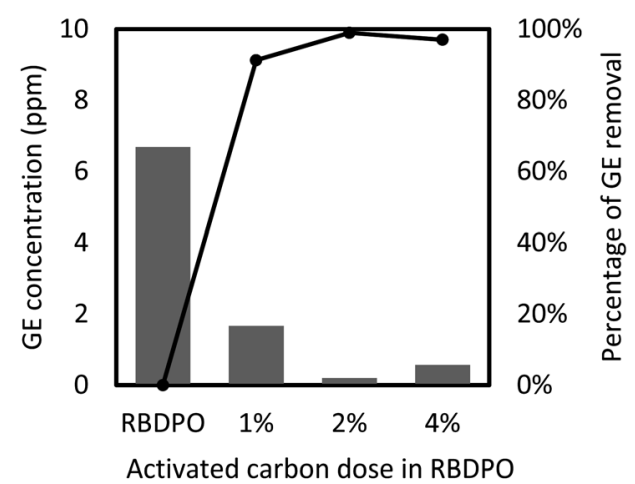

(b)

Fig. 6 The concentration (bar chart) and the percentage of removal (circle with line) of (a) 3-MCPD and (b) GE from RBDPO before and after adsorption with various activated carbon dose at $T=35^{\circ} \mathrm{C}$. 
In this study, the activated carbon was used not only for adsorbing GE, but also for MCPD compounds (3-MCPD and 3MCPDE) removal from RBDPO. About $68 \%$ of the total MCPD compounds were removed from RBDPO (see Fig. 6). Referring to the adsorption percentage, it is clear that the activated carbon can adsorb GE better than total MCPD compounds. The activated carbon had better adsorption to GE than 3-MCPDE because of the molecules size. The 3-MCPD molecule contains two hydroxyl groups that can be esterified to form 3-MCPD monoester of 3-MCPD diester. However, the glycidol molecule only has one hydroxyl group so it just can be a glycidyl monoester. ${ }^{3}$ Meanwhile, in the palm oil, nearly $90 \%$ of 3-MPCDE is in diester form. ${ }^{50}$ Because it has two esters, 3-MCPD diester should have higher molecular size than 3-MCPD monoester and glycidyl ester. Smaller molecules are easier to enter activated carbon's pore, therefore the activated carbon was easier to adsorb GE than 3-MCPDE.

The ability of the activated carbon to adsorb non-polar compounds (3-MCPDE and GE) or polar compounds (3-MCPD and glycidol) is also related to its hydrophobicity/hydrophilicity properties. The hydrophobic/hydrophilic properties of activated carbon are related to its oxygen content. In general, the activated carbon was indicated as a nonpolar adsorbent, so it is possible to adsorb 3-MCPDE and GE which are nonpolar molecules. This results in a strong affinity between the nonpolar molecules and the activated carbon. However, the activated carbon, which exhibits oxygen, will have a polar site. ${ }^{51,52}$ Therefore, the activated carbon has the ability to adsorb polar compounds such as 2-MCPD, 3-MCPD, and glycidol (nonesterified form). Previous research has proven that polar compounds such as water can bond to activated carbon via hydrogen bonding followed by additional water molecule groupings at this site. ${ }^{51,52}$ The activated carbon modified by acid treatment can induce the surface to become more polar, ${ }^{53}$ and also resulting the adsorbent more selective to adsorb 3-MCPDE, GE, and its non-esterified form which was more polar than triglyceride. In conclusion, the activated carbon is mostly nonpolar, but it also has some polar sites.

The activated carbon can also bind the adsorbates via London dispersion forces that allows to adsorb larger molecules and non-polar molecules. The London dispersion force is a temporary attractive force that occurs when the electrons in two adjacent atoms occupy positions, so the atoms make temporary dipoles to synchronize the distribution of electron. ${ }^{\mathbf{4}}$ The London dispersion force occurs in the non-polar molecules, such as 3-MCPDE and GE. The adsorption of organic matter to activated carbon is influenced by several factors, such as characteristics of organic molecules (polarity, functional groups), characteristics of activated carbon (surface area, pore size distribution and functional groups on the surface), and operating conditions (temperature, pressure, time, adsorbent dose). ${ }^{55,56}$ Moreover, based on research conducted by Li et al. (2012), the adsorption process of organic pollutant by using activated carbon particularly occurs via physical adsorption through van der Waals forces between activated carbon and adsorbate. $^{57}$

\section{Conclusions}

Activated carbon has been modified using acid. Acid treatment using $2 \mathrm{~N} \mathrm{HCl}$ on activated carbon gave a good pore volume distribution. It was successfully demonstrated that the activated carbon treated with $2 \mathrm{~N} \mathrm{HCl}$ could adsorb both 3-MCPD and GE. By fitting the equilibrium data using various isotherm models, the maximum adsorption capacity, activation energy, and Gibbs free energy can be estimated, which are $1.484 \mathrm{mg} \mathrm{g}^{-1}$, $0.4 \mathrm{~kJ} \mathrm{~mol}^{-1}$, and $-14.134 \mathrm{~kJ} \mathrm{~mol}^{-1}$, respectively. The low adsorption temperature and the large number of batch stages can increase the percentage of 3-MCPD removal in RBDPO. The best operating conditions to reduce by $80 \%$ of the initial concentration of 3-MCPD were at a temperature of $35^{\circ} \mathrm{C}$ and the operation was carried out in quadruple batch stages carried out in series. On the other hand, the activated carbon can remove about $97 \%$ GE concentration in RBDPO. The activated carbon showed better adsorption of non-polar compounds than adsorption of polar compounds. The removal of GE content in RBDPO was better than the removal of 3-MCPD using activated carbon. The determined adsorption capacity of GE was $29.68 \mathrm{mg} \mathrm{g}^{-1}$. The highest percentage of GE removal was $97 \%$ at $35{ }^{\circ} \mathrm{C}$ operating temperature.

\section{Author contributions}

The authors have participated in this manuscript preparation.

Elvi Restiawaty: conception, critical revising for important intellectual content, data analysis and interpretation, drafting, and approval of the final version; Aulia Maulana, Christian Aslan, Neng Tresna Umi Culsum: execute and investigate the experiment, drafting, data analysis and interpretation; Veinardi Suendo, Norikazu Nishiyama, Yogi Wibisono Budhi: critical revising for important intellectual content.

\section{Conflicts of interest}

There are no conflicts to declare.

\section{Acknowledgements}

The authors gratefully thanks to Badan Pengelola Dana Perkebunan Kelapa Sawit (BPDPKS) for the research grant of PRJ-76/ DPKS/2018.

\section{References}

1 Indonesia Ministry of Agriculture, Outlook of Oil Palm 2017. Indonesia Ministry of Agriculture, 2017.

2 V. Gibon, Palm Oil and Palm Kernel Oil Refining and Fractionation Technology, AOCS Press, 2012.

3 J. Alexander, L. Barregard, M. Bignami, S. Ceccatelli, B. Cottrill, M. Dinovi, L. Edler, B. Grasl-Kraupp, C. Hogstrand, L. R. Hoogenboom, H. K. Knutsen, C. S. Nebbia, I. Oswald, A. Petersen, V. M. Rogiers, M. Rose, A.-C. Roudot, T. Schwerdtle, C. Vleminckx, G. Vollmer and H. Wallac, EFSA J., 2016, 14, 4426. 
4 B. Matthaus, F. Pudel, P. Fehling, K. Vosmann, A. Freudenstein and B. Mattha, Eur. J. Lipid Sci. Technol, 2011, 113, 380-386.

5 N. Bakhiya, K. Abraham, R. Gürtler, K. E. Appel and A. Lampen, Mol. Nutr. Food Res., 2011, 55, 509-521.

6 W. Cheng, G. Liu, X. Wang and L. Han, J. Agric. Food Chem., 2017, 65, 9753-9762.

7 U. Strijowski, V. Heinz and K. Franke, Eur. J. Lipid Sci. Technol., 2011, 113, 387-392.

8 Y. Kurosawa, H. Omori, M. Kuriyama, A. Morita, T. Inoue and F. Yokomizo, European Patent, EP 2471897 B1, 2010.

9 S. E. A. Sharaf El-Deen and G. E. Sharaf El-Deen, Sep. Sci. Technol., 2015, 50, 1469-1479.

10 A. Seco, P. Marzal, C. Gabaldón and J. Ferrer, Sep. Sci. Technol., 1999, 34, 1577-1593.

11 A. Khamkeaw, B. Jongsomjit, J. Robison and M. Phisalaphong, Sep. Sci. Technol., 2019, 54, 2180-2193.

12 W. C. Lim, C. Srinivasakannan and V. Doshi, Sep. Sci. Technol., 2012, 47, 886-895.

13 Ö. Gerçel and H. F. Gerçel, Sep. Sci. Technol., 2009, 44, 20782095.

14 A. Eslami, S. M. Borghei, A. Rashidi and A. Takdastan, Sep. Sci. Technol., 2018, 53, 2536-2549.

15 V. M. Matsis and H. P. Grigoropoulou, Sep. Sci. Technol., 2011, 46, 2004-2021.

16 A. García-Mendieta, M. Solache-Ríos and M. T. Olguín, Sep. Sci. Technol., 2003, 38, 2549-2564.

17 N. Yoshida, Y. Hirota, Y. Uchida, T. Asada, N. Kobayashi and N. Nishiyama, Microporous Mesoporous Mater., 2018, 272, 217-221.

18 P. Balderas-Hernandez, J. G. Ibanez, J. J. Godinez-Ramirez and F. Almada-Calvo, Chem. Educ., 2006, 11, 267-270.

19 M. Danish, R. Hashim, M. N. M. Ibrahim, M. Rafatullah, T. Ahmad and O. Sulaiman, BioResources, 2011, 6, 30193033.

20 A. M. Puziy, O. I. Poddubnaya, A. Martínez-Alonso, F. SuárezGarcía and J. M. D. Tascón, Carbon, 2002, 40, 1493-1505.

21 Z. A. Talitha, N. Andarwulan and D. N. Faridah, J. Oil Palm, 2020, 3, 11-22.

22 F. Wöhrlin, H. Fry and A. Preiß-Weigert, Collaborative Study for the Determination of 3-MCPD-Fatty Acid Esters in Edible Fats and Oils, Federal Institute for Risk Assessment, 2011.

23 K. Y. Foo and B. H. Hameed, Chem. Eng. J., 2010, 156, 2-10. 24 MATLAB, version 9.0.0.341360 (R2016a), The MathWorks Inc., Massachusetts, 2016.

25 S. Lowell and J. E. Shields, Powder Surface Area and Porosity, Springer, Netherlands, 1991.

26 S. Wang and G. Q. M. Lu, Carbon, 1998, 36, 283-292.

27 G. Lota, P. Krawczyk, K. Lota, A. Sierczyńska, Ł. Kolanowski, M. Baraniak and T. Buchwald, J. Solid State Electrochem., 2016, 20, 2857-2864.

28 J. Shu, S. Cheng, H. Xia, L. Zhang, J. Peng, C. Li and S. Zhang, RSC Adv., 2017, 7, 14395-14405.

29 W. Shen, Z. Li and Y. Liu, Recent Pat. Chem. Eng., 2010, 1, 2740.
30 I. Kubovský, D. Kačíková and F. Kačík, Polymers, 2020, 12, 485.

31 H. Yang, R. Yan, H. Chen, D. H. Lee and C. Zheng, Fuel, 2007, 86, 1781-1788.

32 B.-J. Lin, B. Colin, W.-H. Chen, A. Pétrissans, P. Rousset and M. Pétrissans, J. Anal. Appl. Pyrolysis, 2018, 130, 8-18.

33 L. Li, S. Liu and J. Liu, J. Hazard. Mater., 2011, 192, 683-690.

34 J. M. Dias, M. C. M. Alvim-ferraz, M. F. Almeida and M. Sa, J. Environ. Manage., 2007, 85, 833-846.

35 Z. Sun, L. Chai, Y. Shu, Q. Li, M. Liu and D. Qiu, Colloids Surf., A, 2017, 530, 53-59.

36 G. R. Desiraju and T. Steiner, The Weak Hydrogen Bond, Oxford University Press, Oxford, 1999.

37 G. A. Jeffrey and W. Saenger, Hydrogen Bonding in Biological Structures, Springer, Berlin, 1991.

38 P. R. Roberge, Handbook of Corrosion Engineering, McGrawHill, USA, 2000.

39 D. Dittmann, et al., Sci. Rep., 2020, 10, 6695.

40 S. Mopoung, P. Moonsri, W. Palas and S. Khumpai, Sci. World J., 2015, 2015, 415961.

41 U. Beker, B. Ganbold, H. Dertli and D. D. Gülbayir, Energy Convers. Manage., 2010, 51, 235-240.

42 M. E. Fernandez, G. V. Nunell, P. R. Bonelli and A. L. Cukierman, Ind. Crops Prod., 2014, 62, 437-445.

43 A. M. Carvajal-Bernal, F. Gómez, L. Giraldo and J. C. MorenoPiraján, Microporous Mesoporous Mater., 2015, 209, 150-156.

44 D. K. Gupta, A. V. Voronina, V. S. Semenishchev and S. Chatterjee, Green Adsorbents Pollut. Remov. Innov. Mater., Springer, 2018, pp. 377-396.

45 E. A. Emam, Am. J. Environ. Prot., 2013, 2, 161.

46 M. I. Kandah, R. Shawabkeh and M. A. ef Al-Zboon, Appl. Surf. Sci., 2006, 253, 821-826.

47 Y. Ahn, S. Choi and S.-Y. Kwak, J. Environ. Chem. Eng., 2020, 8, 104456.

48 R. Weißhaar, Eur. J. Lipid Sci. Technol., 2008, 110, 183-186. 49 J. E. Park, E. J. Kim, M. J. Park and E. S. Lee, Energies, 2019, 12, 2169.

50 K. Yamazaki, M. Ogiso, S. Isagawa, T. Urushiyama, T. Ukena and N. Kibune, Food Addit. Contam., Part A: Chem., Anal., Control, Exposure Risk Assess., 2013, 30, 52-68.

51 D. Pan and M. Jaroniec, Langmuir, 1996, 12, 3657-3665.

52 E. A. Müller and K. E. Gubbins, Carbon, 1998, 36, 1433-1438. 53 W. Chwialkowski, Enhancing Activated Carbon Adsorption of Polar Compounds from Used Frying Oil: Nitric Acid and Hydrogen Peroxide Treatments, 3rd Euro Fed Lipid Congress: Oils, Fats and Lipids in a Changing World, 2004.

54 J. Feher, Quantitative Human Physiology: An Introduction, Academic Press, USA, 2012.

55 Q.-S. Liu, T. Zheng, P. Wang, J.-P. Jiang and N. Li, Chem. Eng. J., 2010, 157, 348-356.

56 L. Li, P. A. Quinlivan and D. R. U. Knappe, Carbon, 2002, 40, 2085-2100.

57 L. Li, Z. Sun, H. Li and T. C. Keener, J. Air Waste Manage. Assoc., 2012, 62, 1196-1202. 